\title{
International Society of Urological Pathology (ISUP) Consensus Conference on Handling and Staging of Radical Prostatectomy Specimens: rationale and organization
}

\author{
Lars Egevad ${ }^{1}$, John R Srigley² and Brett Delahunt ${ }^{3}$ \\ ${ }^{1}$ Department of Oncology-Pathology, Karolinska Institutet, Karolinska university hospital Solna, \\ Stockholm, Sweden; ${ }^{2}$ Department of Pathology and Molecular Medicine, McMaster University, Hamilton, ON, \\ Canada and ${ }^{3}$ Department of Pathology and Molecular Medicine, Wellington School of Medicine and Health \\ Sciences, University of Otago, Wellington, New Zealand
}

\begin{abstract}
The 2009 International Society of Urological Pathology consensus conference in Boston, made recommendations regarding the standardization of pathology reporting of radical prostatectomy specimens. The activities of the conference were coordinated through five workgroups. The results are presented in five separate reports covering (1) specimen handling, (2) T2 substaging and prostate cancer volume, (3) extraprostatic extension, lymphovascular invasion and locally advanced disease, (4) seminal vesicles and lymph node metastases and (5) surgical margins. In this introductory article we describe some novel features of the organization of the consensus process. Following the completion of a pre-meeting survey conference, participants discussed and voted on 43 specific issues of contention relating to the pathological reporting of radical prostatectomy specimens. Consensus, defined as agreement by at least $65 \%$ of participants present, was achieved for 30 questions.

Modern Pathology (2011) 24, 1-5; doi:10.1038/modpathol.2010.159; published online 27 August 2010
\end{abstract}

Keywords: adenocarcinoma; prognosis; prostate; radical prostatectomy; stage

The clinical importance of the details contained within pathology reports for radical prostatectomy specimens has increased in recent years. Patients found to have adverse histopathological findings may now be offered a variety of adjuvant therapies, such as radiotherapy, chemotherapy or hormonal manipulation, alone or in combination. ${ }^{1}$ It is likely that these treatment options will develop further as increasing insights are gained into novel therapeutic targets; thus, the role of the pathologist is now shifting from the mere reporting of a diagnosis to the provision of guidance for tailored therapies. In view of this there is now an increasing necessity for radical prostatectomy specimens to be handled in

Correspondence: Dr L Egevad, MD, PhD, Department of OncologyPathology, Karolinska Institutet, Karolinska university hospital Solna, Stockholm 17176, Sweden.

E-mail: lars.egevad@ki.se

Received 14 May 2010; revised 19 July 2010; accepted 20 July 2010; published online 27 August 2010 such a way so as to ensure that these data are accurately assessed and reported. In recent years there has been increasing recognition that detailed guidelines are required, to promote consistency in pathologic reporting and the collection of appropriate prognostic information for patients undergoing attempted curative treatment for prostate adenocarcinoma. In response to this the International Society of Urological Pathology (ISUP) undertook to organize a consensus meeting to address these issues in Boston, Massachusetts, USA during March 2009. The results of the meeting are presented in this introductory paper and five subsequent workgroup reports.

The ISUP is the international professional organization for the sub-specialty of urological pathology and has a major role in defining the reporting standards for tumors of the urological and male genital systems. The Society discharges this role through the hosting of consensus meetings designed to assess evolving scientific evidence and set 
appropriate standards. Recently the ISUP has hosted consensus meetings that focused upon the grading of carcinomas of the urinary bladder, as well as Gleason grading of prostatic adenocarcinoma. ${ }^{2,3}$ As in the past, participation at these consensus meetings was by invitation, with attendance restricted to acknowledged specialists in the field. The advantage of this model is that it may be assumed that delegates have true expertize in the area and that a wide breadth of relevant experience will be represented at the meeting. With this method of participant recruitment there is, however, a risk that selection bias may influence consensus decisions. In particular it could be assumed that there will usually be a strong over-representation of academic pathologists, and as a consequence any subsequent recommendations may not reflect acceptable practice in non-academic community hospitals and private practice. To counter this possible selection bias it was agreed that consensus recommendations should not deviate widely from what was felt to be practicable for pathologists working in a busy routine laboratory. To help accomplish this goal it was decided to that all senior fellows in urological pathology, under the supervision of ISUP members as of August 2008, would be invited to participate in the consensus process. Residents who had not completed formal training in anatomical pathology were, however, not eligible to participate.

Although this consensus conference involved a review of the published literature on handling, staging and reporting adenocarcinoma of the prostate, a traditional evidence-based approach looking at the quality and strength of evidence was not employed. This was considered, however, it was felt that along with many other areas of pathology practice, there was insufficient relevant data regarding randomized controlled trials, cohort and case-control studies relating to the handling and reporting of radical prostatectomy specimens.

\section{Materials and methods}

\section{Pre-Meeting Process}

All communications were handled by e-mail through the Secretary of the ISUP (Lars Egevad). A pre-meeting survey was circulated with the purpose of collecting data relating to current practice. The survey questions were based on those of a survey recently conducted amongst 217 European pathologists, ${ }^{4}$ however, the questions were modified by the consensus conference conveners to focus on areas considered to be particularly problematic.

The consensus process was chaired by the authors who are all officers of the ISUP. Five workgroups (Table 1), each consisting of a chair and three additional members with specialist expertize relevant to the assigned workgroup topic, were established. The workgroup chairmen reviewed the draft survey questions and made appropriate
Table 1 Workgroups of consensus meeting

$$
\begin{array}{ll}
W G & \text { Objectives } \\
\hline 1 & \text { Handling of radical prostatectomy specimen } \\
2 & \text { T2 substaging and prostate cancer volume } \\
3 & \text { Extraprostatic extension, lymphovascular invasion and } \\
& \text { locally advanced disease } \\
4 & \text { Seminal vesicles and lymph nodes } \\
5 & \text { Surgical margins }
\end{array}
$$

WG, workgroup.

amendments that were then approved by all workgroup members. In its final form, the survey had a multiple-choice format with additional space for comments. Access to the survey was by e-mail invitation and only those members, who had completed this before the December 2008 cutoff date, were considered eligible to participate at the consensus conference.

Responses to the survey were received from 157 members from 26 countries (Table 2). This represented $62 \%$ of those invited to participate. Among this group, $90(57 \%)$ were from North America, 9 $(6 \%)$ from South America, 37 (23\%) from Europe, 15 $(7 \%)$ from Asia and $6(4 \%)$ from Australia or New Zealand. The principal practice of the participants was described as university/academic by 110 (70\%), community hospital by $19(12 \%)$, private healthcare by $18(12 \%)$ and other institutions, such as military hospitals by $10(6 \%)$.

\section{Consensus conference}

The formal consensus conference was convened in conjunction with the 2009 United States and Canadian Academy of Pathology meeting in Boston on March 8. Of the 157 members invited to participate, 116 delegates from 23 countries attended the meeting (Table 2). This included 69 $(62 \%)$ from North America, 6 (5\%) from South America, 22 (19\%) from Europe, 11 (10\%) from Asia and $5(4 \%)$ from Australia and New Zealand. Among the delegates $82(74 \%)$ were from university/ academic practice, $11(10 \%)$ from community hospitals, $11(10 \%)$ from private healthcare and 7 (6\%) from other institutions. Of those who participated, $77(73 \%)$ reported that they were working in laboratories that received more than 100 radical prostatectomy specimens per year.

Representatives from the five working groups presented appropriate background information to the meeting, which consisted of detailed summaries relevant to the focus of their workgroup that had been prepared from the literature. The survey results were then discussed in the context of the relevant literature and at the conclusion of this a series of specific questions were put to the meeting by the workgroup chair. Formal ballot was taken by a show of hands and a count was undertaken by the 
Table 2 Participants in the pre-meeting survey (X) and consensus conference $\left({ }^{*}\right)$

\begin{tabular}{|c|c|c|c|c|c|c|c|}
\hline & \multirow{2}{*}{ First name } & \multirow{2}{*}{ Surname } & & \\
\hline & & & & & & Survey & Conference \\
\hline & & & & James & Kench & $\mathrm{X}$ & * \\
\hline Adebowale & Adeniran & $\mathrm{X}$ & * & Hyun-Jung & Kim & $\mathrm{X}$ & * \\
\hline Hikmat & Al-Ahmadie & $\mathrm{X}$ & * & Peter & Kragel & $\mathrm{X}$ & * \\
\hline Ferran & Algaba & $\mathrm{X}$ & * & Glen & Kristiansen & $\mathrm{X}$ & * \\
\hline Tehmina & Ali & $\mathrm{X}$ & & Zhaoli & Lane & $\mathrm{X}$ & \\
\hline Robert & Allan & $\mathrm{X}$ & * & Peng & Lee & $\mathrm{X}$ & \\
\hline Mahul & Amin & & * & Claudio & Lewin & $\mathrm{X}$ & * \\
\hline Gustavo & Ayala & $\mathrm{X}$ & & Margaret & Lim & $\mathrm{X}$ & \\
\hline Marc & Barry & $\mathrm{X}$ & * & Josep & Lloreta & $\mathrm{X}$ & * \\
\hline Sheldon & Bastacky & $\mathrm{X}$ & * & Massimo & Loda & $\mathrm{X}$ & \\
\hline Dilek & Baydar & $\mathrm{X}$ & * & Antonio & Lopez-Beltran & $\mathrm{X}$ & * \\
\hline Louis & Bégin & $\mathrm{X}$ & * & Scott & Lucia & $\mathrm{X}$ & * \\
\hline David & Berman & $\mathrm{X}$ & & Daniel & Luthringer & $\mathrm{X}$ & * \\
\hline Daniel & Berney & $\mathrm{X}$ & * & Carmen & Luz Menendez & $\mathrm{X}$ & \\
\hline Athanase & Billis & $\mathrm{X}$ & * & Cristina & Magi-Galluzzi & $\mathrm{X}$ & * \\
\hline Tarek & Bishara & $\mathrm{X}$ & & Peter & McCue & $\mathrm{X}$ & * \\
\hline Liliane & Boccon-Gibod & $\mathrm{X}$ & * & Teresa & McHale & $\mathrm{X}$ & * \\
\hline David & Bostwick & & * & Jesse & McKenney & & * \\
\hline Noel & Brownlee & $\mathrm{X}$ & & Maria & Merino & $\mathrm{X}$ & * \\
\hline Tucker & Burks & $\mathrm{X}$ & * & Rodolfo & Montironi & $\mathrm{X}$ & * \\
\hline Christer & Busch & $\mathrm{X}$ & * & Gabriella & Nesi & $\mathrm{X}$ & * \\
\hline Philippe & Camparo & $\mathrm{X}$ & * & George & Netto & $\mathrm{X}$ & * \\
\hline Dengfeng & Cao & $\mathrm{X}$ & & Esther & Oliva & $\mathrm{X}$ & * \\
\hline Preeti & Chaudhri & $\mathrm{X}$ & & Roberto & Orozco & $\mathrm{X}$ & \\
\hline Mingxin & Che & $\mathrm{X}$ & & Adeboye & Osunkoya & $\mathrm{X}$ & * \\
\hline Liang & Cheng & & * & Chin-Chen & Pan & $\mathrm{X}$ & \\
\hline Cynthia & Cohen & $\mathrm{X}$ & * & Gladell & Paner & $\mathrm{X}$ & * \\
\hline Michael & Cohen & $\mathrm{X}$ & & David & Parada & $\mathrm{X}$ & \\
\hline Eva & Compérat & $\mathrm{X}$ & & Anil & Parwani & $\mathrm{X}$ & * \\
\hline Paolo & Cossu-Rocca & $\mathrm{X}$ & & Maria & Picken & $\mathrm{X}$ & * \\
\hline Antonio & Cubilla & $\mathrm{X}$ & & Galina & Pizov & $\mathrm{X}$ & * \\
\hline Paolo & Dalla Palma & $\mathrm{X}$ & & Katia & Ramos Moreira Leite & $\mathrm{X}$ & * \\
\hline Milton & Datta & $\mathrm{X}$ & * & Andrew & Renshaw & $\mathrm{X}$ & * \\
\hline Laurence & de Leval & $\mathrm{X}$ & * & Victor & Reuter & $\mathrm{X}$ & \\
\hline Angelo & De Marzo & $\mathrm{X}$ & & Jae & Ro & $\mathrm{X}$ & * \\
\hline Anna & de Matteis & $\mathrm{X}$ & & Stephen & Rohan & $\mathrm{X}$ & * \\
\hline Brett & Delahunt & $\mathrm{X}$ & * & Ruben & Ronchetti & $\mathrm{X}$ & * \\
\hline Warick & Delprado & $\mathrm{X}$ & * & Jeff & Ross & $\mathrm{X}$ & \\
\hline Anthony & di Sant'Agnese & $\mathrm{X}$ & & Mark & Rubin & & * \\
\hline Pierre-Andre & Diener & $\mathrm{X}$ & & Hemamali & Samaratunga & $\mathrm{X}$ & * \\
\hline Lars & Egevad & $\mathrm{X}$ & * & Anna & Sankila & $\mathrm{X}$ & * \\
\hline Roy & Ehrnström & $\mathrm{X}$ & & Alan & Schned & $\mathrm{X}$ & * \\
\hline Jonathan & Epstein & $\mathrm{X}$ & * & Michael & Scott & $\mathrm{X}$ & \\
\hline Andrew & Evans & $\mathrm{X}$ & * & Isabell & Sesterhenn & $\mathrm{X}$ & * \\
\hline Sara & Falzarano & $\mathrm{X}$ & * & Ahmed & Shabaik & $\mathrm{X}$ & * \\
\hline Samson & Fine & $\mathrm{X}$ & * & Rajal & Shah & $\mathrm{X}$ & * \\
\hline Eddie & Fridman & $\mathrm{X}$ & $*$ & Jonathan & Shanks & $\mathrm{X}$ & * \\
\hline Bungo & Furusato & $\mathrm{X}$ & * & Steven & Shen & $\mathrm{X}$ & * \\
\hline Masakuni & Furusato & $\mathrm{X}$ & & Jungweon & Shim & $\mathrm{X}$ & * \\
\hline Masoud & Ganji & $\mathrm{X}$ & * & Taizo & Shiraishi & $\mathrm{X}$ & * \\
\hline Paul & Gaudin & $\mathrm{X}$ & & Pedro & Soares de Oliveira & $\mathrm{X}$ & * \\
\hline Lisa & Glantz & $\mathrm{X}$ & * & V.O. & Speights, Jr. & $\mathrm{X}$ & * \\
\hline Anuradha & Gopalan & & * & John & Srigley & $\mathrm{X}$ & * \\
\hline David & Griffiths & $\mathrm{X}$ & & Ming-Tse & Sung & $\mathrm{X}$ & * \\
\hline David & Grignon & $\mathrm{X}$ & * & Jeffrey & Sussman & $\mathrm{X}$ & \\
\hline Rainer & Grobholz & $\mathrm{X}$ & * & Sueli & Suzigan & $\mathrm{X}$ & * \\
\hline Charles & Guo & $\mathrm{X}$ & * & Hiroyuki & Takahashi & $\mathrm{X}$ & * \\
\hline Rekha & Gupta & $\mathrm{X}$ & * & Fabio & Tavora & $\mathrm{X}$ & \\
\hline Bora & Gurel & $\mathrm{X}$ & * & Jerome & Taxy & $\mathrm{X}$ & \\
\hline Seife & Hailemariam & $\mathrm{X}$ & * & Bernard & Tetu & $\mathrm{X}$ & * \\
\hline Ardeshir & Hakam & $\mathrm{X}$ & * & Louis & Thienpont & $\mathrm{X}$ & \\
\hline Omar & Hameed & $\mathrm{X}$ & * & Satish & Tickoo & $\mathrm{X}$ & * \\
\hline Donna & Hansel & $\mathrm{X}$ & * & John & Tomaszewski & $\mathrm{X}$ & * \\
\hline Arndt & Hartmann & $\mathrm{X}$ & & Patricia & Troncoso & $\mathrm{X}$ & * \\
\hline R.-Peter & Henke & $\mathrm{X}$ & * & Kiril & Trpkov & $\mathrm{X}$ & * \\
\hline Mehsati & Herawi & $\mathrm{X}$ & * & Lawrence & True & $\mathrm{X}$ & * \\
\hline Michelle & Hirsch & $\mathrm{X}$ & * & Toyonori & Tsuzuki & $\mathrm{X}$ & * \\
\hline Puay & Hoon Tan & $\mathrm{X}$ & & Jennifer & Turner & $\mathrm{X}$ & * \\
\hline Jiaoti & Huang & $\mathrm{X}$ & * & Theo & van der Kwast & $\mathrm{X}$ & * \\
\hline Wei & Huang & $\mathrm{X}$ & * & Geert & van Leenders & $\mathrm{X}$ & \\
\hline Christina & Hulsbergen van de Kaa & $\mathrm{X}$ & * & Wenle & Wang & $\mathrm{X}$ & \\
\hline Peter & Humphrey & $\mathrm{X}$ & * & Mark & Weiss, & $\mathrm{X}$ & * \\
\hline Kenneth & Iczkowski & $\mathrm{X}$ & * & Thorsten & Venzke & $\mathrm{X}$ & \\
\hline Juan & Iturregui & $\mathrm{X}$ & & Thomas & Wheeler & $\mathrm{X}$ & * \\
\hline Rafael & Jimenez & $\mathrm{X}$ & & Kirk & Wojno & $\mathrm{X}$ & * \\
\hline Sonny & Johansson & $\mathrm{X}$ & & Robin & Vollmer & $\mathrm{X}$ & \\
\hline Edward & Jones & $\mathrm{X}$ & * & Keith & Volmar & $\mathrm{X}$ & * \\
\hline Michael & Jones & $\mathrm{X}$ & * & Chin-Lee & $\mathrm{Wu}$ & $\mathrm{X}$ & * \\
\hline Maria & Jose Brito & $\mathrm{X}$ & * & Regina Paula & Xavier Gomes & $\mathrm{X}$ & \\
\hline Laura Irene & Jufe & $\mathrm{X}$ & * & Jorge & Yao & $\mathrm{X}$ & * \\
\hline Soojin & Jung & $\mathrm{X}$ & & Asli & Yilmaz & $\mathrm{X}$ & * \\
\hline Naoki & Kanomata & $\mathrm{X}$ & & Jim & Zhai & $\mathrm{X}$ & * \\
\hline
\end{tabular}

Table 2 Continued

Table 2 Continued 
conference conveners. Ballots in which there was at least $65 \%$ agreement were considered to represent consensus and among the 43 questions that were considered, consensus was reached in 30 (70\%).

\section{Statistical Methods}

$\chi^{2}$ analysis was used for comparison of distribution of the survey replies. A $P$-value of $<0.05$ was considered significant.

\section{Results and Discussion}

\section{Geographic Variation of Practice}

Analysis of the geographic variation in practice was based upon the replies received from the premeeting survey. For analytical purposes, continents other than North America were grouped together as there were no major differences in the procedures followed by pathologists from these geographical locations. However, when the practices of North American pathologists were compared with the practices of pathologists from outside North America, it was noted that in North America unfixed prostate glands were more commonly received by laboratories (64 vs $30 \%, P<0.001$ ), that fresh tissue was more likely to be harvested for research purposes (78 vs $45 \%, P<0.001$ ), that the prostatic apex was more likely to be sampled using the cone method with subsequent radial sectioning (42 vs $19 \%, P=0.006$ ) and that the term bladder neck margin was most frequently used to designate the upper surgical margin of the radical prostatectomy specimen (78 vs $40 \%, P<0.001$ ). Conversely it was found that embedding of the entire prostate gland (46 vs $78 \%, P<0.001$ ) or the entire seminal vesicles (30 vs $49 \%, P<0.001$ ) was undertaken less frequently in North America.

\section{Pre-Meeting Survey Results and Consensus Conference Decisions}

The purpose of the pre-meeting survey was to collect information relating to the current practices of participating experts and by using a web-based survey, it was clear that the results would be unbiased by discussions among the delegates. At the meeting it was emphasized that consensus recommendations should define a minimum standard that would be feasible for most practicing pathologists to achieve, however, it was emphasized that these should not necessarily reflect the current practices of the experts. Team leaders gave presentations of literature-based evidence and these were debated by delegates before voting.

There were some areas where consensus recommendations differed from the survey results. In particular only $24 \%$ of survey respondents registered the prostate weight independent of seminal vesicles, whereas this procedure was recommended by $67 \%$ of participants at the meeting. Arguments were presented at the meeting as to why the prostate weight may be of greater utility than the combined weight of the prostate and seminal vesicles. The major arguments in favor of weighing the prostate separate from the seminal vesicles were; the variable size of seminal vesicles, varying surgical routines leading to total or subtotal removal of seminal vesicles and a need to correlate gross findings with preoperative imaging and PSA density.

Only $24 \%$ of experts reported the routine partial embedding of radical prostatectomy specimens and, although a majority of respondents noted that they always embedded all tissue from the prostate gland, there was an almost equal split of the votes favoring partial and total embedding at the meeting. This apparent discrepancy resulted from the decision of delegates at the consensus conference that the meeting should produce recommendations relating to minimum requirements that could be internationally accepted, rather than a description of personal practices. It was also noted that financial considerations could inhibit extensive/total examination of surgical specimens.

In the survey, the use of the cone method of sampling, with sagittal slicing, did not reach a two-thirds majority to qualify as a consensus for examination of either the prostatic apex $(58 \%)$ or base $(50 \%)$. Despite this, there was overwhelming support for recommending the use of this technique at the meeting that resulted from the presentation of arguments as to why the shave method and cone method of sampling, with radial slicing, were technically inferior.

Some variation in the interpretation of staging was evident when the results of the survey and consensus conference were compared. According to the survey, $85 \%$ of respondents employed the pT2 substaging category either for clinical or academic purposes. At the consensus conference $66 \%$ of delegates expressed the opinion that the defining features of the current pT2 substaging category were inappropriate when confronted with detailed arguments regarding its shortcomings. Microscopic bladder neck involvement was categorized as pT3 by $37 \%$ of survey respondents, whereas $92 \%$ of meeting delegates favored a designation of pT3a, in line with current recommendations. ${ }^{5,6}$

The diameter of the largest lymph node metastasis was routinely reported by $30 \%$ of experts in the survey, however, in line with the findings from recent studies, ${ }^{7-9}$ there was consensus from $82 \%$ of delegates that reporting of this measure should be mandatory. Extra-nodal extension of lymph node metastases was reported by $88 \%$ of the survey respondents, but obligatory reporting of this was supported by only $62 \%$ of the conference delegates, after considering evidence that this finding is not of prognostic significance. ${ }^{7}$ 


\section{Conclusions}

This consensus meeting was organized according to some novel principles, including a broad invitation of all members of ISUP, activation of the participants by using a pre-meeting web-based survey, presenting evidence-based background data and casting votes through ballots at the conference. The results are presented and discussed in five separate workgroup reports that appear in this issue. The recommendations supported by the participants at this consensus conference have already been incorporated into some international guidelines for the reporting of radical prostatectomy specimens. ${ }^{10,11}$ It is anticipated that the results will further influence other guideline processes and staging systems, including the TNM staging of prostate adenocarcinoma.

\section{Disclosure/conflict of Interest}

The authors declare no conflict of interest.

\section{References}

1 Gonzalez JR, Laudano MA, McCann TR, et al. A review of high-risk prostate cancer and the role of neoadjuvant and adjuvant therapies. World J Urol 2008;26:475-480.

2 Epstein JI, Amin MB, Reuter VR, et al. The World Health Organization/International Society of Urological Pathology consensus classification of urothelial (transitional cell) neoplasms of the urinary bladder. Am J Surg Pathol 1998;22:1435-1448.
3 Epstein JI, Allsbrook Jr WC, Amin MB, et al. The 2005 International Society of Urological Pathology (ISUP) consensus conference on Gleason grading of prostatic carcinoma. Am J Surg Pathol 2005;29:1228-1242.

4 Egevad L, Algaba F, Berney DM, et al. Handling and reporting of radical prostatectomy specimens in Europe: a web-based survey by the European Network of Uropathology (ENUP). Histopathology 2008;53: 333-339.

5 Dash A, Sanda MG, Yu M, et al. Prostate cancer involving the bladder neck: recurrence-free survival and implications for AJCC staging modification. American Joint Committee on Cancer. Urology 2002; 60:276-280.

6 Yossepowitch O, Sircar K, Scardino PT, et al. Bladder neck involvement in pathological stage pT4 radical prostatectomy specimens is not an independent prognostic factor. J Urol 2002;168:2011-2015.

7 Cheng L, Pisansky TM, Ramnani DM, et al. Extranodal extension in lymph node-positive prostate cancer. Mod Pathol 2000;13:113-118.

8 Cheng L, Bergstralh EJ, Cheville JC, et al. Cancer volume of lymph node metastasis predicts progression in prostate cancer. Am J Surg Pathol 1998;22: 1491-1500.

9 Boormans JL, Wildhagen MF, Bangma CH, et al. Histopathological characteristics of lymph node metastases predict cancer-specific survival in node-positive prostate cancer. BJU Int 2008;102:1589-1593.

10 Srigley JR, Humphrey PA, Amin MB, et al. Protocol for the examination of specimens from patients with carcinoma of the prostate gland. Arch Pathol Lab Med 2009;133:1568-1576.

11 Kench J, Clouston D, Delahunt B, et al. Royal College of Pathologists of Australasia prostate cancer (Radical Prostatectomy) structured reporting protocol. 2010, 54pp.http://www.rcpa.edu.au/Publications/Structured Reporting/CancerProtocols.htm. 